\title{
Studies on Agrobacterium Mediated in Planta Genetic Transformation in Black Gram (Vigna mungo L.) Cultivar VBN 3
}

\author{
Nukala Sumanth Kumar and R. Anandan* \\ Department of Genetics and Plant Breeding, Faculty of Agriculture, Annamalai University, \\ Annamalai Nagar-608 002, Tamil Nadu, India \\ *Corresponding author
}

\begin{tabular}{|l|}
\hline Ke y w or d $\mathbf{s}$ \\
Back gram, \\
Cotyledon, $n p t ~ I I$, \\
crylAcF \\
\hline Article Info \\
\hline Accepted: \\
04 April 2018 \\
Available Online: \\
10 May 2018 \\
\hline \hline
\end{tabular}

\section{A B S T R A C T}

In vitro regeneration and in planta transformation protocols were standardized for the black gram (Vigna mungo L.) cv. VBN 3, an important grain legume. An efficient regeneration protocol was developed using 1-week-old de-embryonated cotyledon as explants. The maximum frequency of shoot regeneration (72.6\%), multiple shoot induction $(6.0 \pm 0.3)$ and shoot elongation was achieved on MS medium supplemented with $3.0 \mathrm{mg} / \mathrm{l}$ 6-benzyl amino purine (BAP) after 4 weeks of culture. Up to $65 \%$ of the regenerated shoots were rooted on MS medium containing $0.5 \mathrm{mg} / 1 \alpha$-naphthalene acetic acid (NAA) within 3 weeks of culture. The in vitro-raised plantlets were successfully hardened first under culture room conditions with $62 \%$ survival rate and then in greenhouse. A binary vector $\mathrm{pBinAR}$ harbouring $c r y l A c F$ gene isolated from $\mathrm{E}$. coli competent cells was transformed into Agrobacterium strain EHA105 using freeze-thaw method and its presence was confirmed by colony PCR analysis of the selected single colonies for examining the presence of the npt II and crylAcF genes. The integrity of plasmid was checked by restriction analysis. Agrobacterium tumifaciens-mediated transformation was performed using strain EHA105 harboring the binary vector pBinAR carrying $c r y l A c F$ gene under the control of CaMV35s promoter where $c r y l A c F$ as insect resistance gene and npt II gene as a selectable markers. Antibiotic sensitivity test was conducted with sprouted half-seed and 1-week-old cotyledons with kanamycin at $50 \mathrm{mg} / \mathrm{l}$ completely inhibited the shoot formation and explants survival. Genetic transformation experiments were carried out using cotyledonary explants and it was found to be unsuccessful event while regenerating the transformed cotyledons due to its recalcitrance nature. Therefore, Agrobacterium mediated in planta transformation was performed using sprouted half-seed explants of VBN 3. The transformation event consisted of sonicating the explants for 3 minutes and vacuum infiltration ( $750 \mathrm{~mm}$ of $\mathrm{Hg}$ ) for 2 minutes in Agrobacterium (pBinAR-crylAcF) and co-cultivation for 3 days in MS medium with acetosyringone $(100 \mu \mathrm{M})$. The transformed explants forming shoots were selected in MS medium supplemented with kanamycin $50 \mathrm{mg} / \mathrm{l}$. The non-transformed shoots were completely bleached after selection. The presence and integration of $n p t I I$ and $c r y l A c F$ transgenes into the black gram genome was confirmed by polymerase chain reaction (PCR). PCR analysis in 20 selected putative transformed black gram plantlets did not show amplification for crylAcF and npt II genes. Work is in progress to grow the T0 seeds for molecular characterization of the inserted transgene among $\mathrm{T} 1$ plants. 


\section{Introduction}

Black gram (Vigna mungo L. Hepper) or urd bean is a widely grown grain legume belongs to family Fabaceae and genus Vigna. It is reported to have originated in South Asia and distributed in tropical and subtropical regions of India (Kapildev et al., 2016). It is a nitrogen fixing, short duration and tropical pulse grown as either sole or as intercrop or as fallow crop in many parts of India. Black gram seed consists of protein $(25-28 \%)$, oil (1.0-1.5\%), fibre (3.5-4.5\%), ash (4.5-5.5\%) and carbohydrates $(62-65 \%)$ and are commonly used as ingredients in making dal for curries, soup, sweets and snacks. Globally pulses are grown on 81 million hectares of area with an annual production of 73.21 million tonnes (FAOSTAT, 2013-2014). Among the pulses, pigeon pea, black gram and green gram are the major contributors of the total pulses production. Black gram production in the country is largely concentrated in five states viz., Uttar Pradesh (U.P), Maharashtra, Madhya Pradesh, Andhra Pradesh and Tamil Nadu. These five states together contribute for about $70 \%$ of total production in the country. The average productivity of black gram in Tamil Nadu is about $412 \mathrm{~kg} / \mathrm{ha}$ which is very low when compared to Indian average of 555 $\mathrm{kg} / \mathrm{ha}$.

The major production constraints in black gram include several stress factors (biotic and abiotic), which led to significant yield loss are susceptibility to yellow mosaic virus (VMYMCV) (Sahoo et al., 2002), fungal pathogens (powdery mildew, cercospora leaf spot), bruchids (Sahoo et al., 2002), and pod borer (Rao and Chand, 2006; Sarma and Borah, 2004). Gram pod borer (Helicoverpa armigera) is considered a serious lepidopteran pest of the crop, and has resulted in significant economic losses $(40-60 \%)$ in the world and India has not been an exception. The production of black gram is still insufficient to meet the requirement of increasing human population. Hence, it is important to develop genetically engineered black gram cultivars with $c r y$ genes for pod borer resistance.

Legumes are extremely recalcitrant to in vitro culture and genetic transformation. Limited reports are available in connection with Agrobacterium-mediated transformation in black gram using different explants, such as cotyledonary node and shoot apex (Saini and Jaiwal, 2005). Although the previous reports showed positive results in black gram transformation, many constraints still exist to limit the improvement of black gram with desirable traits. Agrobacterium-mediated in planta transformation is an effective method to produce huge number of transgenic lines in a shorter time.

In planta transformation method has been adopted in several crops such as Glycine max, Arachis hypogeae, Arabidopsis thaliana, Raphanus sativus, Cicer arietinum, Beta vulgaris, Gossypium hirsutum, Solanum lycopersicum and Brassica juncea. Molecular markers can be used as diagnostic tool to identify the presence of a specific gene with accuracy and transfer it to different backgrounds. During pyramiding of genes it is difficult to select plants with multiple resistance genes based on phenotype alone as there may be epistatic effects. The main objective of this study is to transform black gram cv. VBN 3 via sonication and vacuum infiltration of sprouted seeds with Agrobacterium harboring a synthetic $c r y l A c F$ gene.

\section{Materials and Methods}

Genetically pure black gram seeds of VBN 3 were collected from The National Pulses Research Centre at Vambam in Pudukkottai district, Tamil Nadu, India was used for the present investigation. 


\section{Surface sterilization of explants}

Sterilization is the method which results in the removal of all microorganisms and other pathogens from an object or surface by treating it with chemicals or subjecting it to high heat or radiation. Mature black gram seeds were surface sterilized in $0.1 \%$ mercuric chloride $\left(\mathrm{HgCl}_{2}\right)$ for $30 \mathrm{sec}$ and rinsed thoroughly with sterile double distilled water for three times. Seeds are used either directly or germinated for a week for the cotyledonary explants (Plate 1).

\section{Explants preparations}

For the isolation of cotyledonary explants, surface sterilized seeds were aseptically transferred to the petri dish containing hormone free medium and cultured at $25 \pm$ $2^{\circ} \mathrm{C}$ in the dark for about a week. A week old cotyledons were dissected by giving a cut at the proximal end of the seed with the outer skin removed and inoculated on MS (Murashige and Skoog) media (Plate 1).

\section{Media preparations}

All experiments were conducted using MS basal medium. Unless /otherwise stated, 30g/1 of sucrose was used as a carbon source and phytagel was used as a gelling agent at a rate of $4.0 \mathrm{~g} / \mathrm{l}$ in all media, plant growth regulators were added prior to autoclaving. The $\mathrm{pH}$ of the medium was adjusted to 5.8 by $1 \mathrm{~N} \mathrm{NaOH}$ or $1 \mathrm{~N} \mathrm{HCl}$. The media were steam sterilized in a autoclave under $1.5 \mathrm{~kg} / \mathrm{cm}$ and $121^{\circ} \mathrm{C}$ for 15 min. around $25 \mathrm{ml}$ of medium was dispensed into petri dishes $(90 \times 10 \mathrm{~mm})$ and culture were maintained at $25 \pm 2^{\circ} \mathrm{C}$ under $16 \mathrm{~h} \mathrm{cool-}$ white fluorescent lights with $8 \mathrm{~h}$ dark period.

\section{Adventitious shoot induction}

The deembryonated cotyledon explants were cultured on MS medium with various concentrations of 6-benzylaminopurine
(BAP). All the cultures were transferred to fresh medium after every 15 days. MS basal medium without exogenous supply of growth regulators was used as control. After 6 weeks, percentage of shoot organogenesis, average number of shoots per explants and mean shoot length were recorded. The nature of plantlets was also evaluated qualitatively as normal shoots, abnormal shoots and multiple shoots. A total of twenty five cotyledonary explants were used with five replications per treatment and the experiment was repeated thrice. For each treatment, data were scored 4 to 6 weeks after initiation of culture. (Plate.1)

\section{Rooting and hardening of plantlets}

Plantlets with well-developed shoots (2 to 4 $\mathrm{cm}$ long) were excised from shoot clusters and placed on rooting media (half- or full-strength MS, MS+ indole-3-butyric acid (IBA 0.5 and $1.0 \mathrm{mg} / \mathrm{l})$ or MS+ $\alpha$-naphthalene acetic acid (NAA 0.5 and $1.0 \mathrm{mg} / \mathrm{l}$ ) for 3 to 4 weeks. The rooted shoots were successfully uprooted gently from magenta vessel and adhered phytagel from roots was removed by washing with sterile water and transferred to pot containing pot containing sand, or clay soil, or vermicompost and sand and vermicompost (1:1) and maintained in the transgenic greenhouse for hardening. The plastic pots were covered with polythene and holes were increased gradually to facilitate exchange of gases. These potted plants were maintained in the green house with 50\% sunlight reduction, $25 \pm 2{ }^{\circ} \mathrm{C}$ temperature, and intermittent mist. A total of ten adventitious shoots were used with three replications per treatment and the experiment was repeated thrice. (Plate.1)

\section{Bacterial transformation of pBinAR- cry1AcF in EHA105 cells}

\section{Gene construct}

In the present study, the binary vector pBinAR harbouring crylAcF gene $(1.863 \mathrm{~kb})$ flanked 
by CaMV35s promoter and OCS polyA terminator and $n p t I I$ as selectable markers was used for transformation. This construct was obtained from Dr. Rohini Sreevasthsa, senior scientist, NRCPB, New Delhi, and the same was maintained in Escherichia coli (DH5a) competent cells.

Preparation of $E$. coli $\mathrm{DH} 5 \alpha$ competent cells

A single colony of DH5 $\alpha$ was inoculated in 3 $\mathrm{ml}$ of LB broth and allowed to grow overnight in a rotary shaker at $37^{\circ} \mathrm{C}$ for $125 \mathrm{rpm}$. $1 \mathrm{ml}$ of overnight grown culture was inoculated in $30 \mathrm{ml}$ of LB broth and subculture is done. The cell suspension is maintained at $0^{\circ} \mathrm{C}$ for 20 minutes by keeping it on ice. Then, it is centrifuged at $5000 \mathrm{rpm}$ for 10 minutes at $4^{\circ} \mathrm{C}$. The supernatant was discarded and the pellet was resuspended in sterile ice cold $100 \mathrm{mM}$ $\mathrm{Cacl}_{2}$ and kept on ice for immediate use.

Mobilization of plasmid into $E$. coli DH5a component cells

To an aliquot of $200 \mu \mathrm{l}$ competent cell suspension of DH5 $\alpha, 1 \mu \mathrm{l}(100 \mathrm{ng})$ of the plasmid pBinAR - crylAcF was mixed and incubated on ice for $30 \mathrm{~min}$ by giving a heat shock at $42^{\circ} \mathrm{C}$ for 90 seconds and again it was incubated on ice for 5-10 $\mathrm{min}$. Then, to the suspension $1 \mathrm{ml}$ LB broth was added and incubated at $37^{\circ} \mathrm{C}$ for 1 hour. After incubation, $50-100 \mu \mathrm{l}$ of the cell suspension was placed on LB agar medium with kanamycin $(50 \mathrm{mg} / \mathrm{l})$ and incubated at $37^{\circ} \mathrm{C}$ overnight.

\section{Isolation of plasmid DNA $E$. coli by alkaline lysis method}

Two $\mathrm{ml}$ of bacterial culture is added in a centrifuge tube and centrifuged at $12000 \mathrm{rpm}$ for $1 \mathrm{~min}$ at $4^{\circ} \mathrm{C}$. The supernatant was discarded and the suspending pellet was added with $100 \mu \mathrm{l}$ ice cold solution I ( $25 \mathrm{mM}$ Tris base, $10 \mathrm{mM}$ EDTA and $50 \mathrm{mM}$ glucose) and vortex it followed by which $200 \mu$ l of solution II $(0.2 \mathrm{~N} \mathrm{NaOH}$ and $1 \%$ SDS $)$ was added and $150 \mu$ l of solution III ( 5 M Potassium acetate, Glacial acetic acid and double distilled water) was added and kept on ice for $5 \mathrm{mins}$ and centrifuged at $12000 \mathrm{rpm}$ for $5 \mathrm{mins}$ at $4^{\circ} \mathrm{C}$. Now the supernatant is added to a new Eppondorf tube along with $300 \mu$ l of cold isopropanol solution and allowing it for 10-20 mins at $25^{\circ} \mathrm{C}$. The above mentioned ingredients were centrifuged for $5 \mathrm{mins}$ at $4^{\circ} \mathrm{C}$. Decanting the isopropanol the pellet is dried and rinsed with $70 \%$ ethanol and again the pellet was dried removing the supernatant. And the pellet is dissolved in $50 \mu \mathrm{l}$ of $\mathrm{TE}$ buffer and stored at $-20^{\circ} \mathrm{C}$.

\section{Restriction digestion of plasmid DNA}

Restriction digestion of plasmid DNA isolated from transformed $\mathrm{DH} 5 \alpha$ cells was done as per the standard procedures with the view to confirm the presence of $\mathrm{pBinAR}$ and to check the structural integrity of the construct. Approximately 200-250 ng of plasmid DNA was digested with restriction enzymes HindIII + EcoRI, BamHI + SaII, nptII in appropriate buffers at $37^{\circ} \mathrm{C}$ for 1 hour. The DNA sample along with buffer and restriction enzymes were added to a clean tube and incubated at the digestion temperature (usually $37^{\circ} \mathrm{C}$ ) for 1 hour. The digestion was stopped by heat inactivation $\left(65^{\circ} \mathrm{C}\right.$ for 15 minutes $)$ or by addition of $10 \mathrm{Mm}$ final concentration EDTA. The digested products were analyzed in $0.8 \%$ agarose gel.

\section{Agarose gel electrophoresis}

Required amount of agarose was weighed $(0.8 \% \mathrm{w} / \mathrm{v})$ and melted in $1 \mathrm{xTBE}$ buffer. Ethidium bromide (1-2 $\mu 1)$ was added from the stock $\left(10 \mathrm{mg} / \mathrm{l} \mathrm{H}_{2} \mathrm{O}\right)$. After cooling to 50$55^{\circ} \mathrm{C}$, the mixture was poured on to a preset template with an appropriate comb. DNA to be analysed was mixed with the gel loading 
buffer and loaded into the well. Electrophoresis was carried out at $60 \mathrm{~V}$, to separate the restriction products.

\section{Transformation of $\mathrm{pBinAR}$ construct to EHA105 cells}

The binary vector pBinAR harbouring crylAcF isolated from E. coli competent cells was transformed into Agrobacterium strain EHA105 using the freeze-thaw method. The Agrobacterium competent cells were prepared in a similar way as for E. coli and stored at $80^{\circ} \mathrm{C}$. Thaw the competent Agrobacterium cells on ice if it is stored on $-70^{\circ} \mathrm{C}$ or use the freshly prepared competent cells (use $250 \mu \mathrm{l}$ per transformation reaction) and add DNA (1$5 \mu \mathrm{l}$ of $\mathrm{CaCl}_{2}$ purified DNA or $10 \mu \mathrm{l}$ of standard E. coli miniprep DNA.) Incubate the mixture on ice for 5minutes. Transfer the mixture to liquid nitrogen and incubate for 5minutes and again, do the same for another 5 minutes in a water bath at $37^{\circ} \mathrm{C}$. Add $1 \mathrm{ml}$ of LB broth to each tube, seal it and place the tubes on a rocking table for 2-4 hours at room temperature. Collect the cells by spinning briefly in a micro centrifuge and spread them on two LB agar plates containing antibiotic (kanamycin $50 \mathrm{mg} / \mathrm{l}$ ) for the T-DNA vector. Incubate the cells for 2 days at $28^{\circ} \mathrm{C}$. (Plate.2)

\section{Colony PCR}

PCR was conducted in a thermocycler using the plasmid DNA of selected single colonies. It was carried out for examining the presence of the nptII and crylAcF genes. The primers used for amplification of the nptII gene were 5'-GAGGCTATTCGGCTATGACTG-3' and 5'-ATCGGGAGGGGCGATACCGTA-3', generating a $750 \mathrm{bp}$ product and the primers for $\quad c r y l A c F$ gene were 5'AACCCAAACATCAACGAGTGC -3 ' and 5'-TTATGCAGTCCAAGATGTCC -3' resulting in a $664 \mathrm{bp}$ product. The PCR reaction mixture $(20 \mu \mathrm{l})$ contained $0.3 \mathrm{U}$ Taq
DNA polymerase, $1 \mathrm{X}$ assay buffer $(10 \mathrm{mM}$ $\mathrm{pH} 9.0$ Tris- $\mathrm{HCl} 50 \mathrm{mM} \mathrm{Kcl}, 1.5 \mathrm{mM} \mathrm{MgCl}$, $0.01 \%$ gelatin), $150 \mu \mathrm{M}$ of each dNTPs, $1 \mu \mathrm{l}$ of each forward and reverse primer at a final concentration of $0.25 \mu \mathrm{M}$, and a single colonies of bacteria. The PCR reaction profile for $c r y l A c F$ gene comprised of 30 cycles, with strand separation at $94^{\circ} \mathrm{C}$ for 30 seconds annealing at $60^{\circ} \mathrm{C}$ for 30 seconds and extension at $72^{\circ} \mathrm{C}$ for 1 minute.

The program was extended for 10 minutes at $72^{\circ} \mathrm{C}$. The PCR reaction profile for $n p t I I$ gene comprised 32 cycles, with denaturation at $94^{\circ} \mathrm{C}$ for $1 \mathrm{~min}$, annealing at $58^{\circ} \mathrm{C}$ for 1 minute 30 seconds and an extension at $72^{\circ} \mathrm{C}$ for 1 minute, with final extension at $72^{\circ} \mathrm{C}$ for 10minutes. The PCR products were electrophoresed on a $1 \%$ agarose gel, stained with ethidium bromide, and visualized under transilluminator (Plate 4).

Agrobacterium mediated transformation of black gram with cry 1 AcF gene using Tissue culture dependent genetic transformation using cotyledonary explants

\section{Explant and media preparation}

\section{Kanamycin sensitivity assay}

For selection of transformed shoots an optimal concentration of kanamycin was determined by culturing non transferred (control) cotyledonory explants on regeneration medium (MS + $3.0 \mathrm{mg} / \mathrm{l}$ BAP) containing various concentrations of kanamycin $(15,30$, $50,70,90,100,120 \mathrm{mg} / \mathrm{l})$. For each treatment, data on drying and survival percentage of explants were scored 2 to 3 weeks after initiation of culture.

\section{Preparation of Agrobacterium culture}

Agrobacterium bacterium strain EHA105 (pBinAR) was streaked on a YEP agar 
medium $(10 \mathrm{~g}$ yeast extract, $10 \mathrm{~g}$ bacto peptone, $5 \mathrm{~g} \mathrm{Nacl}, 15 \mathrm{~g} / \mathrm{l}$ of agar, $\mathrm{pH} 7.0)$. A single colony was transferred to $5 \mathrm{ml}$ of YEP liquid medium with kanamycin $(50 \mathrm{mg} / \mathrm{l})$ and the culture was incubated at $28^{\circ} \mathrm{C}$ on a rotary shaker at $200 \mathrm{rpm}$ from the overnight culture, $0.5 \mathrm{ml}$ was transferred to $20 \mathrm{ml}$ YEP liquid medium with kanamycin $(50 \mathrm{mg} / \mathrm{l})$. The culture was allowed to grow for $12 \mathrm{~h}$. The culture was centrifuged at $3000 \mathrm{rpm}$ for 10 minutes and the pellet resuspended in $20 \mathrm{ml}$ of YEP liquid medium containing $100 \mu \mathrm{M}$ acetosyringone at the density of $10^{9}$ cells $/ \mathrm{ml}$ $\left(\mathrm{OD}_{600}=1\right)$ (Toriyama and Hinata 1985 ; Hiei et al., 1994).

Infection, cocultivation, and selection of transformants

The cotyledonary explants excised from 1week-old seedlings were immersed in bacterial suspension for 20-25 min with occasional shaking.

Inoculated explants were blotted on sterile filter paper and cocultured in Petri dishes containing co-cultivation medium (MS medium supplemented with $100 \mu \mathrm{M}$ acetosyringone for 3 days under a $16 \mathrm{~h}$ photoperiod at $25 \pm 2{ }^{\circ} \mathrm{C}$. After co-cultivation, the explants were washed three to four times with sterile distilled water and blotted dry on sterile filter paper. The explants were cultured on MS medium containing BAP ( $3 \mathrm{mg} / \mathrm{l}), 50$ $\mathrm{mg} / \mathrm{l}$ kanamycin, $400 \mathrm{mg} / \mathrm{l}$ cefotaxime and $0.8 \%$ agar for shoot regeneration.

The explants were sub-cultured on fresh medium containing the same level of antibiotics every 2 weeks for 4-6 weeks. Green shoots recovered on selection medium were rooted on MS medium containing 0.5 $\mathrm{mg} / \mathrm{l} \mathrm{NAA}$ and $50 \mathrm{mg} / \mathrm{l}$ kanamycin. The putative transformed plants were established in soil and grown to maturity to collect to seeds.
Tissue culture-independent genetic transformation (in planta) using half-seed explants via sonication and vacuum infiltration

\section{Surface sterilization and explant preparation}

The healthy seeds were surface sterilized using $0.1 \%$ mercuric chloride $\left(\mathrm{HgCl}_{2}\right)$ for 1 min and in $70 \%(\mathrm{v} / \mathrm{v})$ ethanol for $1 \mathrm{~min}$ and then seeds were washed thoroughly for 6 times with sterile double distilled water to eliminate the sterilants completely. The surface sterilized seeds were kept overnight in $500 \mathrm{ml}$ Erlenmeyer flask containing $100 \mathrm{ml}$ liquid half strength MS medium for sprouting in an orbital shaker (120 rpm). The sprouted seeds were de-coated aseptically and dissected into two halves. Decoated half-seed was used as explants for in planta transformation study.

Effect of kanamycin on black gram seeds of cv. VBN 3

For selection of transformed plants from explants an optimal concentration of kanamycin was determined culturing the seeds on MS medium supplemented with different concentrations of kanamycin $(15,30,50,70$, $90,100,120 \mathrm{mg} / \mathrm{l})$. A total of twenty explants were used with five replications per treatment and the experiment was repeated thrice. For each treatment, data on drying and survival percentage of explants were scored 2 to 3 weeks after initiation of culture (Table 4).

\section{Preparation of Agrobacterium culture}

Transformation via Sonication and Vacuum infiltration

The in planta transformation protocols in black gram genotypes using sonication and vacuum infiltration durations, and acetosyringone concentrations were followed 
according to Kapil Dev et al., (2016), with some slight modifications. The sterilized halfseed explants were transferred into Agrobacterium suspensions containing acetosyringone $(100 \mu \mathrm{M})$. Sonication was carried for $0,1,2,3,4,5$ and 6-min using a bath sonicator (model 1510 Branson, Branson Ultrasonics, Kanagawa, Japan). Then the seeds were transferred into fresh Agrobacterium suspension and subjected to vacuum infiltration for $0,1,2,3,4,5$ and 6 min at $750 \mathrm{~mm}$ of $\mathrm{Hg}$ using a desiccator (Tarsons, Kolkata, India) connected to a vacuum pump (Indian high vacuum pumps, Bangalore, India). The sonicated cum vacuum-infiltrated explants were incubated in Agrobacterium suspension medium supplemented with optimized concentration of acetosyringone $100 \mu \mathrm{M}$ for $1 \mathrm{~h}$ under dark for Agrobacterium infection. Following this, the Agrobacterium infected seeds were blot dried and then co-cultivated in MS medium without hormone containing $100 \mu \mathrm{M}$ of acetosyringone for 3 dyas. The infected seeds were washed with sterile distilled water containing $500 \mathrm{mg} / \mathrm{l}$ cefotaxime (Alkem laboratories, Mumbai, India) and blot-dried on a sterilized filter paper and inoculated onto solid MS basal medium containing appropriate hygromycin or kanamycin as selectable marker and incubated at $25 \pm 2{ }^{\circ} \mathrm{C}$ under $16 \mathrm{~h}$ photo period. The explants were sub-cultured twice at 5 days interval. After 4 weeks, the well rooted survival seedlings were transferred to earthen pots containing the potting mixture (1:1:1 of red soil, sand and farm yard manure) kept in green house and maintained $85 \%$ relative humidity at $25 \pm 2{ }^{\circ} \mathrm{C}$ for acclimatization (Table 7).

\section{Molecular analysis of putative transgenic plantlets}

The antibiotic resistant plants were subjected to molecular confirmation of the transgene using PCR with gene specific primers.

\section{DNA extraction}

Extraction of the DNA from the samples was carried out according to the procedures of Doyle and Doyle (1990). Leaf tissue samples $(2 \mathrm{~g})$ were collected from the putative transgenics of cotyledonory explants, and grinded in pestle and mortar by using pre heated $\left(65^{\circ} \mathrm{C}\right)$ Cetyl Trimethyl Ammonium Bromide (CTAB) buffer. Around $15 \mu \mathrm{l}$ of CTAB buffer was added. Extracted samples were incubated in the water bath for 30 minutes at $65^{\circ} \mathrm{C}$. After incubation equal volume of chloroform: isoamyl alcohol (24:1) was added in to the tubes and inverted for 5 to $10 \mathrm{~min}$ to mix. Then the tubes were kept in centrifuge for 10 minutes at $4000 \mathrm{rpm}$. Then the aqueous layer was transferred in to the new Eppondorf tubes. An amount of equal volume of isoproponol (stored at $-20^{\circ} \mathrm{C}$ ) was added to each sample and inverted gently to mix and kept at overnight at $4^{\circ} \mathrm{C}$.

The samples were centrifuged at $10000 \mathrm{rpm}$ for 10 minutes on the next day. The supernatant was discarded from each sample and the pellets settled in the bottom were air dried for 30 minutes. A quantity of $100 \mu \mathrm{l}$ of TE buffer was added into each sample and stored it overnight at $4^{\circ} \mathrm{C}$. RNAse $(5 \mu \mathrm{l})$ was added into each sample to exclude the RNA contamination and kept for incubation at $37^{\circ} \mathrm{C}$ for 30minutes. An amount of equal volume of chloroform: isoamyl alcohol (24:1) was added to the tubes and centrifuged at $1000 \mathrm{rpm}$ for 5 minutes and the supernatant was taken into the fresh tubes. To which the twice the volume of absolute ethanol and $1 / 10^{\text {th }}$ volume of $3 \mathrm{M}$ sodium acetate was added and kept the samples at $-70^{\circ} \mathrm{C}$ for 1 hour. Centrifuge the tubes at $10000 \mathrm{rpm}$ for 10 minutes. The supernatant was discarded and $200 \mu \mathrm{l}$ of $70 \%$ ethanol was added and centrifuged at 5000 rpm for 5 minutes. The supernatant was discarded and the pellet was air dried for 30 minutes. The pellet was resuspended by using 
$100 \mu \mathrm{TE}$ buffer and kept at $-20^{\circ} \mathrm{C}$ for long term use.

\section{DNA quality and quantity estimation}

The concentration of DNA was estimated spectrophotometrically. In spectrophotometric analysis, $5 \mu \mathrm{l}$ of DNA was diluted to $3000 \mu \mathrm{l}$ of TE buffer. The spectrophotometer readings were recorded at 260 and $280 \mathrm{~nm}$. DNA concentration was calculated using OD values at $260 \mathrm{~nm}$ using the following formula concentration of DNA $(\mu 1 / \mathrm{ml})=$ OD at 260 nm X 50.

\section{PCR analysis}

PCR was performed to amplify nptII and crylAcF genes with a few modifications. Reactions were performed in in a final volume of $25 \mu \mathrm{l}$ and the mixture contained $50-100$ ng of genomic DNA, $2.5 \mu \mathrm{l}$ of 10X PCR buffer $(10 \mathrm{mM}$ Tris- $\mathrm{HCl} \mathrm{pH} 9.0,50 \mathrm{mM} \mathrm{KCl}$, $1.5 \mathrm{mM} \mathrm{MgCl}_{2}, 0.001 \%$ (w/v) gelatin), 200 $\mathrm{mM}$ of each of dNTPs, $70 \mathrm{ng}$ of upstream and downstream primers and 2 units of Taq DNA polymerase. Amplification was performed in a thermocycler (Mastercycler Personal, Eppendorf, USA).

\section{nptII gene}

Forward primer (5'- GAGGCTAT TCGGCTATGACTG-3') and reverse primer (5'- ATCGGGAGGGGCGATACCGTA- 3') were used to amplify a $750 \mathrm{bp}$ long internal fragment of the nptII gene. The PCR reaction profile for nptII gene comprised 32 cycles, with denaturation at $94^{\circ} \mathrm{C}$ for 1 minute, annealing at $58^{\circ} \mathrm{C}$ for 1 minute 30 seconds and an extension at $72{ }^{\circ} \mathrm{C}$ for 1 minute, with final extension at $72^{\circ} \mathrm{C}$ for 10 minutes. After amplification, $10 \mu \mathrm{l}$ of the product was used for electrophoretic analysis on $1.5 \%$ agarose gels.
cry1AcF

Forward primer of $c r y l A c F$ gene (5'AACCCAAACATCAACGAGTGC -3') and reverse primer (5'- TTATGCAGTCCAAG ATGTCC -3') were used to amplify a 664 bp long fragment of $c r y l A c F$. The PCR reaction profile for $c r y l A c F$ gene comprised of 30 cycles, with strand separation at $94^{\circ} \mathrm{C}$ for 30 seconds, annealing at $60^{\circ} \mathrm{C}$ for 30 seconds, and extension at $72^{\circ} \mathrm{C}$ for 1 minute. The program was extended for 10 minutes at $72^{\circ} \mathrm{C}$. After amplification, $10 \mu \mathrm{l}$ of the product was used for electrophoretic analysis on $1.5 \%$ agarose gels.

\section{Results and Discussion}

It is mandatory to develop genetically engineered black gram cultivars. Legumes particularly $V$. mungo, are extremely recalcitrant to in vitro culture and genetic transformation (Atif et al., 2013). In the particle bombardment method, germinated embryos of black gram were used as explant.

Although the previous reports showed positive results in black gram transformation, many constraints still exist to limit the improvement of black gram with desirable traits.

Vamban 3 an Indian balck gram cultivar was selected for this study. The explants were decoated half seed with embryonic axis was used in this study. For the regeneration protocol on MS medium supplemented with various growth regulators, cotyledonary explants were evaluated. In vitro regeneration of $\mathrm{VBN}-3$ black gram cultivar form cotyledonary tissues was achieved on MS medium supplemented with various concentrations of cytokinis (BAP). Maximum shoot regeneration frequency was observed on $4.0 \mathrm{mg} / \mathrm{l} \mathrm{BAP}$ medium and also stated that BAP was found to enhance regeneration frequency. 
Plate.1 Regeneration from 1-week-old cotyledon explants of black gram cv. VBN-3

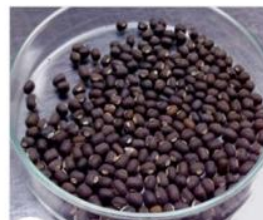

a

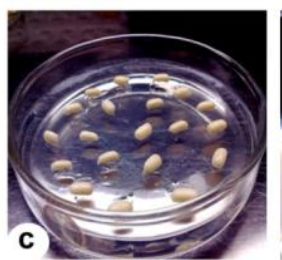

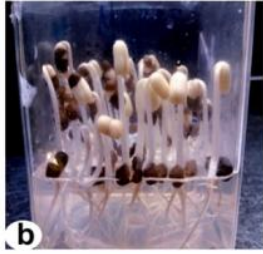

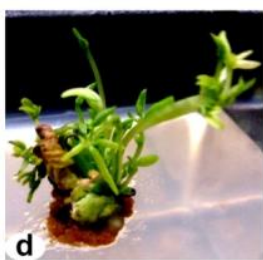

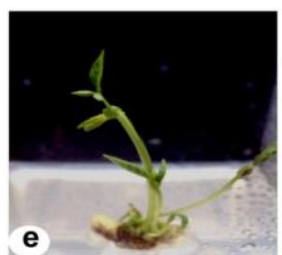
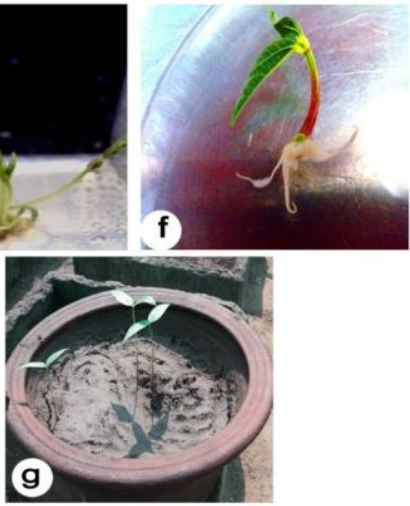

a. Surface sterilized seeds of black gram: b. Germination of seeds on MS basal medium: c. Deembryonated cotyledon dissected from in vitro grown seedlings: d. Development of multiple shoots from dembryonated cotyledon on MS medium containing BAP (3 mg/l): e. Elongated shoots with normal leaves on MS medium + BAP (3 mg/l): f. Rooting on MS medium containing NAA $(0.5 \mathrm{mg} / \mathrm{l})$.

Plate.2 Rest Physical map of pBINAR harboring $c r y l A c F$ gene

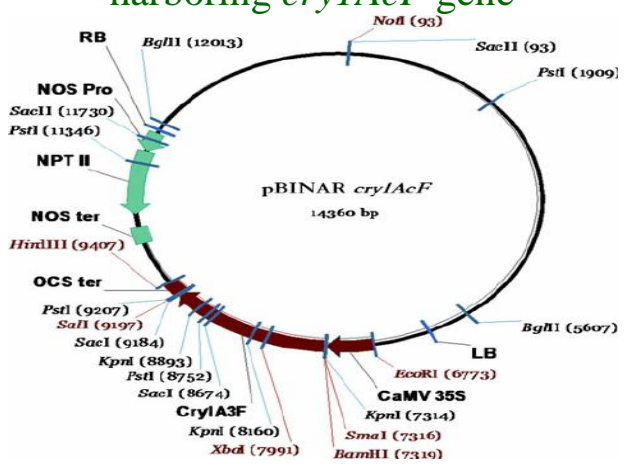

Plate. 4 Colony PCR analysis of $c r y 1 A c F$ and $n p t I I$ genes in plasmid using gene specific primers

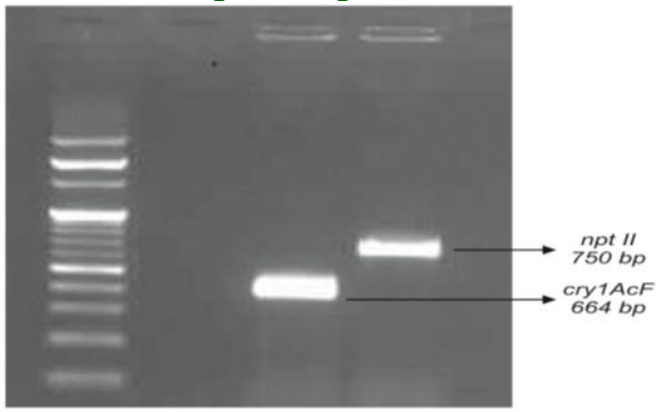

Plate.3 Restriction digestion analysis of pBinAR harbouring $c r y l A c F$ gene

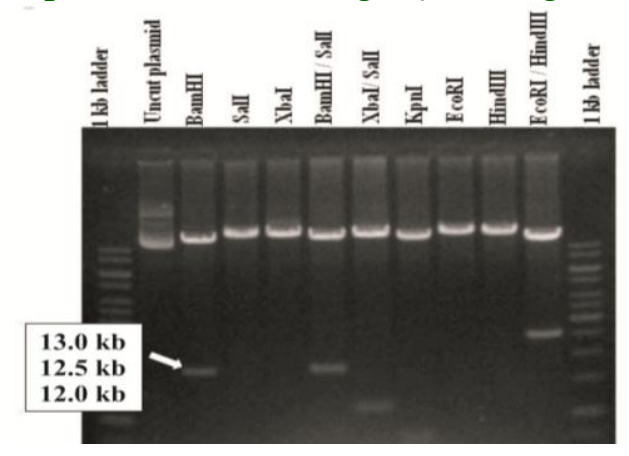

Plate.5 Kanamycin sensitivity test in sprouted

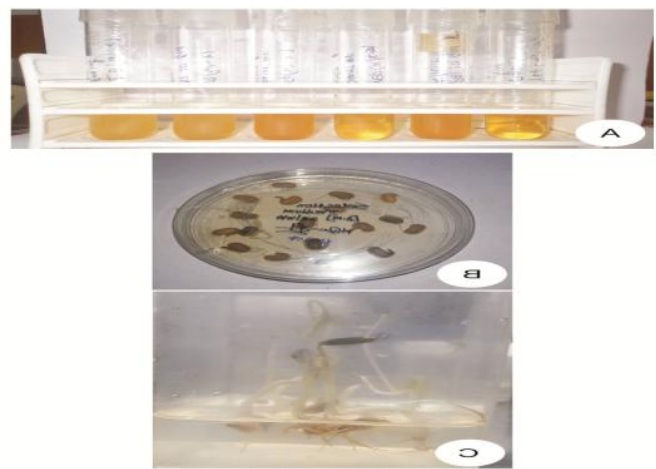

A. Agrobacterium culture harbouring cry1 AcF gene.

B. Agrobacterium transferred cotyledons on selection medium (MS + BAP \& kanamycin) 
Plate.6 Agrobacterium mediated in planta transformation of black gram cv. VBN-3 through Sonication and vacuum infiltration
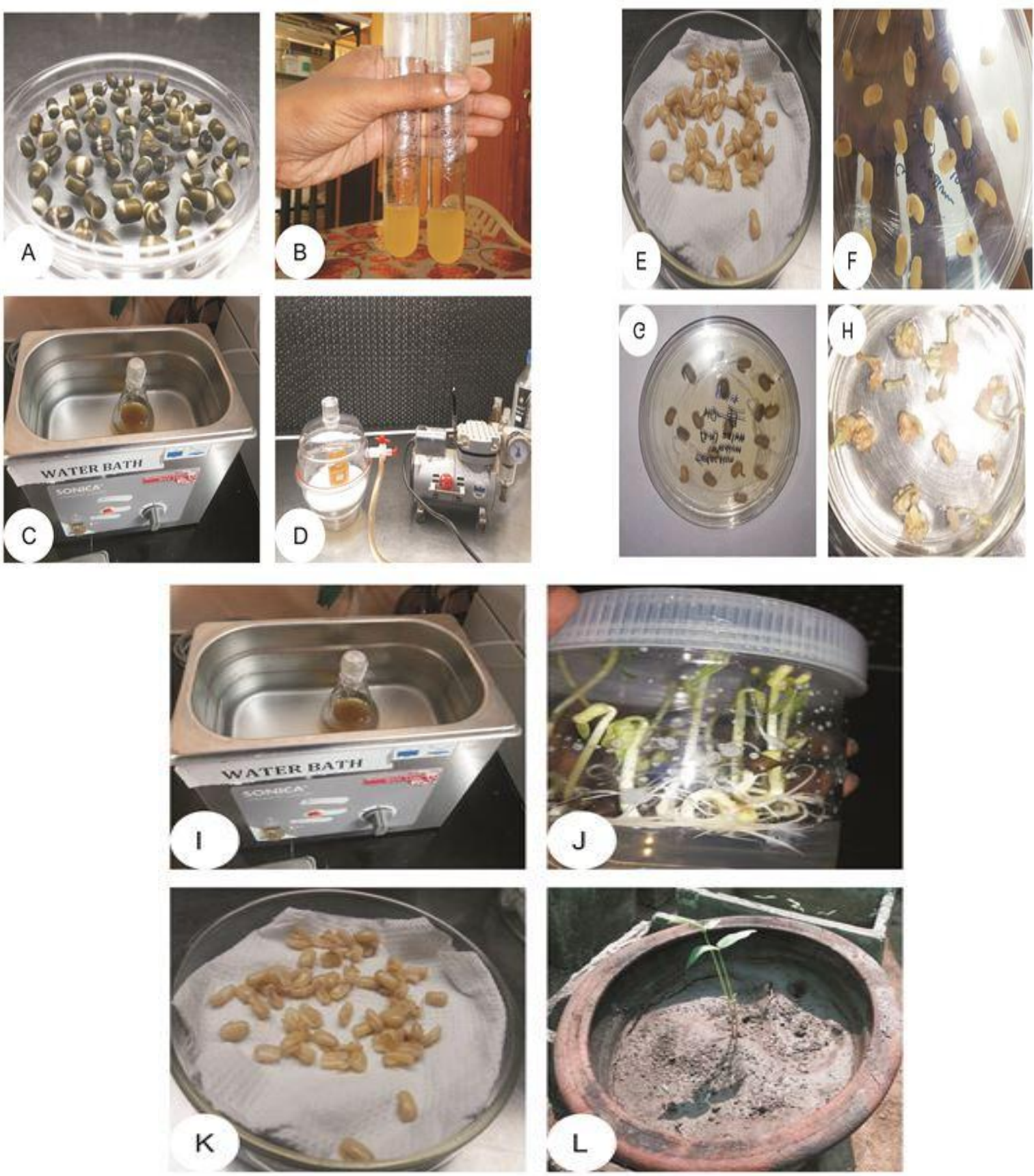

A). Seeds with plumules and radicles, B). Agrobacterium strain EHA105 harboring $c r y 1 A c F$ gene, C). Sonication of sprouted half seeds of black gram in Agrobacterium suspension, D). Vacuum infiltration of sonicated half-seeds of black gram in Agrobacterium suspension using vacuum pump and dessication, E). Blot dried seeds after Agrobacterium infection, F). Agrobacterium infected seeds in co-cultivation medium for 3 days, G). Maintenance of seeds in selection medium after 3 days of co-cultivation, $\mathrm{H} \& \mathrm{I}$ ). Putative transformants forming multiple shoots on selection medium after 2 weeks $(\mathrm{H})$ and 4 weeks (I). J). rooting of transformed shoots in MS + kanamycin (50 $\mathrm{mg} / \mathrm{l}$ ), K). Drying of non-transformed shoots on selection medium after 6 weeks of culture, L). putatively transformed plants acclamatized I greenhouse condition after 8 weeks 
Table.1 Effect of different concentrations of cytokinin on adventitious shoot initiation from cotyledon explants of black gram cv. VBN-3

\begin{tabular}{|l|c|c|c|}
\hline BAP $(\mathrm{mg} / \mathrm{l})$ & $\begin{array}{c}\text { Regeneration } \\
\text { response }(\%)\end{array}$ & $\begin{array}{c}\text { Mean no. of shoots/ } \\
\text { explant }(\text { mean } \pm \text { SE) }\end{array}$ & Nature of plantlets \\
\hline $\mathbf{0 . 0}$ & $0.00 \pm 0.00$ & 0.00 & - \\
\hline $\mathbf{0 . 5}$ & $15.0 \pm 1.52 \mathrm{a}$ & $1.0 \pm 0.5 \mathrm{a}$ & + \\
\hline $\mathbf{1 . 0}$ & $18.0 \pm 0.70 \mathrm{ef}$ & $1.0 \pm 0.7 \mathrm{a}$ & + \\
\hline $\mathbf{2 . 0}$ & $37.2 \pm 0.83 \mathrm{f}$ & $2.0 \pm 0.4 \mathrm{c}$ & + \\
\hline 3.0 & $72.6 \pm 1.34 \mathrm{~g}$ & $6.0 \pm 0.3 \mathrm{e}$ & ++ \\
\hline $\mathbf{4 . 0}$ & $55.0 \pm 1.58 \mathrm{de}$ & $3.0 \pm 0.5 \mathrm{~d}$ & ++ \\
\hline $\mathbf{5 . 0}$ & $45.8 \pm 0.83 \mathrm{~d}$ & $2.0 \pm 0.3 \mathrm{~b}$ & + \\
\hline $\mathbf{6 . 0}$ & $34.2 \pm 0.83 \mathrm{c}$ & $2.0 \pm 0.5 \mathrm{~b}$ & - \\
\hline 7.0 & $22.2 \pm 0.83 \mathrm{~b}$ & $1.0 \pm 0.4 \mathrm{a}$ & - \\
\hline $\mathbf{8 . 0}$ & $8.4 \pm 1.14 \mathrm{~b}$ & $1.0 \pm 0.5 \mathrm{a}$ & - \\
\hline $\mathbf{1 0 . 0}$ & $6.0 \pm 1.58 \mathrm{a}$ & $1.0 \pm 0.2 \mathrm{a}$ & + \\
\hline
\end{tabular}

Values represent means \pm SE of 20 replicates per treatment in three repeated experiments. Values followed by the same letter are not significantly different at $P<0.05$ according to Duncan's multiple range tests.

Nature of plantlets was evaluated qualitatively as -: no, +: abnormal shoots ++: normal shoots with leaves, +++: multiple shoots.

Table.2 Effect of different levels of auxins and MS medium strengths on rooting of adventitious shoots of black gram cv. VBN 3

\begin{tabular}{|l|c|c|c|}
\hline Culture medium & $\begin{array}{c}\text { Rooting response } \\
\%(\text { mean } \pm \text { SE) }\end{array}$ & $\begin{array}{c}\text { Mean no. of roots/ } \\
\text { shoot }(\text { mean } \pm \text { SE })\end{array}$ & $\begin{array}{c}\text { Plant conversion } \\
\text { rate }^{\mathrm{B}}(\%)\end{array}$ \\
\hline Half MS & $26 \pm 9.8 \mathrm{c}$ & $2.00 \pm .01 \mathrm{~b}$ & $32.0 \pm 5.4 \mathrm{c}$ \\
\hline Full MS & $40 \pm 8.4 \mathrm{c}$ & $2.04 \pm .08 \mathrm{~b}$ & $35.0 \pm 5.4 \mathrm{c}$ \\
\hline MS+NAA $(0.5 \mathrm{mg} / \mathrm{l})$ & $65 \pm 12.5 \mathrm{a}$ & $3.02 \pm .04 \mathrm{a}$ & $62.0 \pm 5.4 \mathrm{a}$ \\
\hline MS+NAA $(1.0 \mathrm{mg} / \mathrm{l})$ & $47 \pm 13.2 \mathrm{c}$ & $2.00 \pm .00 \mathrm{~b}$ & $42.0 \pm 5.4 \mathrm{~b}$ \\
\hline MS+IBA $(0.5 \mathrm{mg} / \mathrm{l})$ & $55 \pm 12.5 \mathrm{~b}$ & $4.50 \pm .08 \mathrm{a}$ & $45.0 \pm 5.4 \mathrm{a}$ \\
\hline MS+IBA $(1.0 \mathrm{mg} / \mathrm{l})$ & $34 \pm 15.4 \mathrm{c}$ & $1.02 \pm .04 \mathrm{c}$ & $37.0 \pm 5.4 \mathrm{~b}$ \\
\hline
\end{tabular}

${ }^{\mathrm{A}} 10$ adventitious shoots/replicate, three replicate/treatment and experiment repeated thrice, data taken after 4 weeks.

${ }^{\mathrm{B}} 10$ plant conversion indicates the plantlets with well-developed shoot and root.

Values followed by the same letter are not significantly different at $P<0.05$ according to Duncan's multiple range tests.

Table.3 Survival ability of hardened plantlets in greenhouse

\section{Hardening media}

\section{Clay soil}

Sand

Vermi compost

Sand and Vermi compost

\section{Survival rate $(\%)($ mean $\pm \mathrm{SE})$}

\begin{tabular}{|c|c|}
\hline $18 \pm 4.5 \mathrm{~d}$ \\
\hline $42 \pm 5.7 \mathrm{c}$ \\
\hline $58 \pm 7.1 \mathrm{~b}$ \\
\hline $72 \pm 10.2 \mathrm{a}$ \\
\hline
\end{tabular}

Values followed by the same letter are not significantly different at $\mathrm{P}<0.05$ according to Duncan's multiple range tests.

${ }^{\mathrm{A}}$ Ten somatic plantlets/treatment and experiment repeated thrice

Each data represent mean $\pm \mathrm{SE}$ of three independent experiments 
Table.4 Effect of kanamycin concentration on survival and adventitious shoot initiation from 1week-old cotyledons of black gram cv. VBN 3

\begin{tabular}{|l|c|c|c|c|}
\hline $\begin{array}{l}\text { Kanamycin } \\
\text { concentration } \\
(\text { mg/l) }\end{array}$ & $\begin{array}{c}\text { No. of } \\
\text { cotyledons/ } \\
\text { treatment }\end{array}$ & $\begin{array}{c}\text { No. of cotyledons } \\
\text { survived }\end{array}$ & Survival \% & Shoot initiation \\
\hline Control & 25 & 25 & 100 & + \\
\hline $\mathbf{1 5}$ & 25 & 22 & 88 & + \\
\hline $\mathbf{3 0}$ & 25 & 10 & 40 & + \\
\hline $\mathbf{5 0}$ & 25 & 0 & 0 & - \\
\hline $\mathbf{7 0}$ & 25 & 0 & 0 & - \\
\hline $\mathbf{9 0}$ & 25 & 0 & 0 & - \\
\hline 100 & 25 & 0 & 0 & - \\
\hline 120 & 25 & 0 & 0 & - \\
\hline
\end{tabular}

$(+)$ enhanced adventitious shoot initiation.

(-) charred cotyledons (absence of shoot initiation).

Table.5 Agrobacterium-mediated transformation of black gram using cotyledonary explants

\begin{tabular}{|l|c|c|c|c|c|c|}
\hline $\begin{array}{l}\text { Experimen } \\
\text { t No. }\end{array}$ & $\begin{array}{c}\text { No. of } \\
\text { explants } \\
\text { co- } \\
\text { cultivated }\end{array}$ & $\begin{array}{c}\text { No. of explants } \\
\text { survived after } \\
\text { third round of } \\
\text { selection }\end{array}$ & $\begin{array}{c}\text { No. of } \\
\text { explants } \\
\text { initiated } \\
\text { shoot }\end{array}$ & $\begin{array}{c}\text { Regeneratio } \\
\text { nefficiency } \\
(\%)\end{array}$ & $\begin{array}{c}\text { Mean no. of } \\
\text { crylAcF } \\
\text { positive } \\
\text { explants }\end{array}$ & $\begin{array}{c}\text { Transformat } \\
\text { ion } \\
\text { efficiency }\end{array}$ \\
\hline $\mathbf{1}$ & 25 & 4 & 1 & 25.0 & - & - \\
\hline $\mathbf{2}$ & 25 & 1 & 0 & 00.0 & - & - \\
\hline $\mathbf{3}$ & 25 & 3 & 1 & 31.7 & - & - \\
\hline $\mathbf{4}$ & 25 & 2 & 1 & 48.2 & - & - \\
\hline 5 & 25 & 1 & 0 & 00.0 & - & - \\
\hline 6 & 25 & 2 & 1 & 49.4 & - & - \\
\hline 7 & 25 & 5 & 3 & 61.0 & - & - \\
\hline 8 & 25 & 2 & 0 & 00.0 & - & - \\
\hline
\end{tabular}

a- selection on MS + kanamycin $(50 \mathrm{mg} / \mathrm{l})$

Table.6 Effect of kanamycin concentration on survival and seed germination of black gram cv. VBN-3

\begin{tabular}{|l|c|c|c|}
\hline Kanamycin concentration $(\mathbf{m g} / \mathbf{l})$ & No. of seeds/ treatment & No. of plants survived & Survival \% \\
\hline Control & 25 & 25 & 95 \\
\hline 15 & 25 & 20 & 80 \\
\hline 30 & 25 & 12 & 48 \\
\hline 50 & 25 & 0 & 0 \\
\hline 70 & 25 & 0 & 0 \\
\hline 90 & 25 & 0 & 0 \\
\hline 100 & 25 & 0 & 0 \\
\hline 120 & 25 & 0 & 0 \\
\hline
\end{tabular}

(+) enhanced seedlings formation.

(-) charred explants (absence of shoot initiation). 
Table.7 Influences of sonication duration and vacuum infiltration duration on in planta transformation efficiency of black gram cv. VBN-3

\begin{tabular}{|c|c|c|c|c|c|}
\hline $\begin{array}{l}\text { Sonication } \\
\text { duration } \\
\text { (min) }\end{array}$ & $\begin{array}{c}\text { Vacuum } \\
\text { infiltration } \\
\text { time (min) }\end{array}$ & $\begin{array}{l}\text { No. of } \\
\text { seeds } \\
\text { infected }\end{array}$ & $\begin{array}{l}\text { Mean no. of } \\
\text { seeds } \\
\text { germinated }^{\mathrm{a}}\end{array}$ & $\begin{array}{c}\text { Mean no. of } \\
\text { crylAcF positive } \\
\text { explants }\end{array}$ & $\begin{array}{c}\text { Transformatio } \\
\text { n efficiency } \\
(\%)\end{array}$ \\
\hline 0 & 0 & 100 & 10 & - & - \\
\hline 1 & - & 100 & 14 & - & - \\
\hline 2 & - & 100 & 23 & - & - \\
\hline 3 & - & 100 & 34 & - & - \\
\hline 4 & - & 100 & 30 & - & - \\
\hline 5 & - & 100 & 25 & - & - \\
\hline 6 & - & 100 & 20 & - & - \\
\hline- & 1 & 100 & 14 & - & - \\
\hline- & 2 & 100 & 42 & - & - \\
\hline- & 3 & 100 & 35 & - & - \\
\hline- & 4 & 100 & 30 & - & - \\
\hline- & 5 & 100 & 24 & - & - \\
\hline- & 6 & 100 & 20 & - & - \\
\hline 3 & 1 & 100 & 18 & - & - \\
\hline 3 & 2 & 100 & 48 & - & - \\
\hline 3 & 3 & 100 & 31 & - & - \\
\hline 3 & 4 & 100 & 24 & - & - \\
\hline 3 & 5 & 100 & 18 & - & - \\
\hline 3 & 6 & 100 & 13 & - & - \\
\hline
\end{tabular}

a- explants on section medium (MS+ kanamycin $50 \mathrm{mg} / \mathrm{l}$ )

In the present study $50 \mathrm{mg} / \mathrm{l}$ kanamycin concentration in the medium caused a drastic decrease in both the frequency of regeneration and number of shoots per explant, hence this concentration was used for the selection of transformed shoots. Using nptII as a selectable marker gene and kanamycin as a selection agent is widely used system for screening transformants in a large variety of plants like mulberry (Bhatnagar and Khurana, 2003), chickpea (Mehrotra et al., 2011). Here, also we used the same selectable marker and were able to achieve complete suppression of non-transformed plants with optimized dose of kanamycin $(50 \mathrm{mg} / \mathrm{l})$. The identification and development of cry genes in transgenic crops for pest management has turned out to be a major accomplishment. A major limitation has been specificity of the $B t$ toxins to only a certain group of lepidopterans pests.

In planta transformation is a tissue culture independent approach to obtain fertile transformed plants. In planta transformation A single colony from Agrobacterium tumefaciens strains was inoculated separately into $30 \mathrm{ml}$ YEP medium amended with the aforementioned antibiotics and incubated at $28{ }^{\circ} \mathrm{C}$ in an orbital shaker set at $180 \mathrm{rpm}$ (Ganapathi et al., 2015). Following cocultivation, the infected seeds were washed with sterile liquid MS medium containing cefotaxime (Alkem laboratories, Mumbai, India). They were then blot-dried on a sterilized filter paper and inoculated onto solid MS basal medium. A total of surviving plants of transformation were used for confirmation of putative transgenic lines by 
PCR analysis by using gene specific primers crylAcF and nptII. However the PCR analysis in 10 selected putative plantlets of blackgram did not shown amplification for crylAcF and nptII genes. This indicates no transgenic shoots were obtained in this study. These results are negatively correlated with the previous works of Ganapathi et al., (2016); Saini and Jaiwal et al., 2003; where they have achieved transformation efficiency of $46.2 \%, 2.05 \%$ and $17 \%$ respectively.

The transformation efficiency $(0.0 \%)$ in the present study may be due to the usage of the cotyledons explants excised from 7 days old seedlings. Future line of research is needed to generate huge number of stable transgenic plants by employing different dilution of overnight bacterial culture $(1: 10,1: 25,1: 50$ and 1:100) to improve regeneration efficiency. In another in planta experiment, presoaked seeds with just emerging plumule were infected by pricking using sterile needle and incubated in Agrobacterium culture. Out of 30 seeds that were subjected to Agrobacterium infection, 20 plantlets that survived the infection process were transferred to the greenhouse.

To sum up biotechnological approaches for the improvement of black gram for growth and yield parameters is a continuous parameter to be assessed. In the present study investigation, genetic transformation using Agrobacterium mediated in planta transformation methods we attempted to evaluate the best methodology for reliable protocol development (Table 1-7). Regeneration attempts using different sources of cytokinins indicated BAP is the best. Nevertheless these attempts need to be refined and approached with still better methodologies which will open up new vistas in the era of black gram transformation and molecular breeding techniques.

\section{References}

Ali, G. M. (2015). Piercing and incubation method of in planta transformation producing stable transgenic plants by over expressing DREBIA gene in tomato (Solanum lycopersicum Mill.). Plant Cell, Tissue and Organ Culture (PCTOC), 120(3): 1139-1157.

Bhatnagar, S., and Khurana, P. (2003). Agrobacterium tumefaciens-mediated transformation of Indian mulberry, Morus indica cv. K2: a time-phased screening strategy. Plant cell reports, 21(7): 669-675.

Doyle, J. J. (1990). Isolation of plant DNA from fresh tissue. Focus, 12: 13-15.

Kapil dev, G., Chinnathambi, A., Sivanandhan, G., Rajesh, M., Vasudevan, V., Mayavan, S. and Ganapathi, A. (2016). High-efficient Agrobacterium-mediated in planta transformation in black gram (Vigna mungo (L.) Hepper). Acta Physiologiae Plantarum, 38(8): 205.

Kapildev, G., Chinnathambi, A., Sivanandhan, G., Rajesh, M., Vasudevan, V., Mayavan, S., and Ganapathi, A. (2016). High-efficient Agrobacterium-mediated in planta transformation in black gram (Vigna mungo (L.) Hepper). Acta Physiologiae Plantarum, 38(8): 205.

Mehrotra, M., Singh, A. K., Sanyal, I., Altosaar, I., and Amla, D. V. (2011). Pyramiding of modified $c r y l A b$ and crylAc genes of Bacillus thuringiensis in transgenic chickpea (Cicer arietinum L.) for improved resistance to pod borer insect Helicoverpa armigera. Euphytica, 182(1): 87.

Rao, CR. and Chand, P. (2006). Impact of different mating approaches in generating variability in blackgram [Vigna mungo (L.) Hepper]. Legume Res, 24: 174-177. 
Sahoo, L., Sugla, T., Jaiwal, PK. (2002). In vitro regeneration and genetic transformation of Vigna species. In: Jaiwal PK, Singh RP (Eds). Biotechnology for improvement of legumes. Kluwer Academic Publishers, Dordrecht. pp. 1-48

Saini, R. and Jaiwal, PK. (2005). Transformation of a recalcitrant grain legume, Vigna mungo L. Hepper, using
Agrobacterium tumefaciens-mediated gene transfer to shoot apical meristem cultures. Plant Cell Reports, 24: 164171.

Saini, R., Jaiwal, S. and Jaiwal, P.K. (2003). Stable genetic transformation of Vigna mungo L. Hepper via Agrobacterium tumefaciens. Plant Cell Rep., 21(9): 851.

\section{How to cite this article:}

Nukala Sumanth Kumar and Anandan, R. 2018. Studies on Agrobacterium Mediated in Planta Genetic Transformation in Black Gram (Vigna mungo L.) Cultivar VBN 3. Int.J.Curr.Microbiol.App.Sci. 7(05): 273-287. doi: https://doi.org/10.20546/ijcmas.2018.705.036 